unreal picture of a tiny baby claiming protection - which the pre-embryo is not; and the only authoritative support for such a view comes from the Church (he means the Roman Catholic Church), in which the position is demonstrably a novelty. At this point St Thomas Aquinas and the animation tradition is properly invoked. Unfortunately on p30 Austin appears to have followed Glanville Williams in his interpretation of St Thomas's language, to assert that he took quickening as the first indication of life. Animatus in Aquinas, as in the writing of philosophers, moralists and canonists for centuries, refers specifically to 'animation' in the Aristotelian sense the point when the morphology of the organism revealed or displayed that its animating or organising principle was a 'rational soul', that of a man and not of an animal. Inevitably animatus came in time to be identified with the subjective experience of quickening (vivificatus) and as such the concept passed into the English common law. This minor blemish detracts little from a very good and useful book.

G R DUNSTAN Department of Theology, The University of Exeter.

\section{Christian Ethics in Health Care}

John Wilkinson, 510 pages, Edinburgh, \{27.50, The Handsel Press, 1988.

This is a very ambitious book intended to guide Christian health workers in the ethical problems they face. By articulating ethical principles for thought and action, Wilkinson hopes to have produced a book of more lasting value than one which proceeded from problems or issues.

The book is in three parts: Christian ethics in outline, Health care ethics in history, and Christian ethics in health care. Given the strong emphasis on a principled approach it is not clear why so many issues get discussed in part three, yet it is just as well because this is the best part of the book. There are chapters on the beginning of life, the close of life, human experimentation and consent, resource allocation, health care relationships, and AIDS. It is not always clear that the Christian contribution to these discussions is as singular or normative as the author might have liked.

Wilkinson stands in a tradition in which theology and ethics cannot be separated. He writes of there being a Christian world view and a Christian ethical system "based on the character of God as revealed in Jesus Christ his Son and on his creation of the world and of man' ( $\mathrm{p} x)$. However, the discussion of particular issues frequently admits a degree of pluralism in Christianity. Whilst a helpful and clear methodology is given in the first section of the book too much of the discussion is frustrating. No one could deal justly with natural morality in six pages or biblical ethics in twelve pages. It would have been useful to have indicated more clearly the authority of the Bible. Its absolute authority seems to become relative as the particular is discussed and the various sources of Christian ethics come into conflict.

A more positive appreciation of the descriptive and analytical strands of ethics might have helped the third section of the book. In one part of the discussion of the beginning of life the phrase 'the termination of pregnancy' is abandoned in favour of 'abortion' and 'the unborn contents of the mother's uterus' in favour of 'child'. The justification is brevity, with no recognition of the value-loaded nature of the descriptions.

Despite these major reservations this book is a fine example of someone wrestling faithfully with ethical dilemmas. There is much to be gained here by Christians involved in health care, though the approach is more limited than the author himself is prepared to admit.

NICHOLAS HOLTAM, Christ Church, Isle of Dogs, London E14.

\section{Ethics in Nursing Practice: Basic Principles and Their Application}

F J Fitzpatrick, 290 pages, London, £9.95, The Linacre Centre, 1988.

This book should carry a more obvious 'government health warning' than it does. That is to say its title does not reveal the fact that it is a book which has more to do with Catholic moral principles and standpoints than with a more general notion of nursing ethics. The fact that the book comes out of the Linacre Centre gives a clue to its purpose and the foreword makes it very clear what this book is about. It states: 'The Governors and staff of the centre were made aware at an early stage in our existence of the need for a comprehensive account of nursing ethics which would be both faithful to Catholic moral tradition and accessible to a wider audience'.

The book stands on its own terms, that is as a guide to Catholic nurses in clinical practice. I am not so sure of its appeal to a 'wider audience'. The chapter dealing with Issues in sexual ethics is perhaps the most obvious example of the book's specific outlook. There are four practices which Fitzpatrick points out are 'objectionable' from the Catholic viewpoint. These are contraception, sterilisation, artificial insemination and in vitro fertilisation. In this chapter the Catholic beliefs are well articulated but little time is given to the idea that those who do not hold these views might have their rights compromised if they are nursed by someone who is primarily concerned with keeping faith and conscience intact.

The position taken leads to some rather bizarre lines of argument. For instance, in an attempt to maintain the inseparable link between the unitive and procreative meanings of human sexual activity Fitzpatrick argues thus: 'If ... sexual intercourse is intrinsically bound up with procreation, and if, also, the begetting and raising of children is appropriate only in the context of a single man-woman couple who undertake an unshakable commitment to care for their children, we can see why extra-marital affairs, homosexual practices and pederasty are to be condemned'.

I have focussed on what I see to be the less useful, in a general sense, aspects of this work and it would be unfair to leave the review at that. The work opens with a few general remarks about caring, the role of the nurse in terms of dependence and independence viz a viz medicine, the primacy of caring in nursing and the importance of health. There is a discussion of codes of ethics and discipline in nursing.

There is a useful introductory account of 'morality and objective truth'. After an enlightening discussion of emotivism and subjective-report theory, Fitzpatrick rather undercuts his, up until then even-handed approach, by asserting that 'although the idea that moral beliefs are not objectively true or false is clearly fashionable at present, nobody who ever makes moral claims - and surely that means all of us - can take it seriously. Clearly there is such a thing as moral truth...'. 